\title{
Limnological evaluation of water in the Rio Grande and Taquacetuba branches of the Billings Complex (São Paulo, Brazil) and management implications
}

(doi:10.4136/ambi-agua.153)

\author{
Viviane Moschini-Carlos ${ }^{1}$; Leandro Gomes de Freitas ${ }^{1}$; Marcelo Pompêoº \\ ${ }^{1}$ UNESP, Campus de Sorocaba, SP \\ E-mail: viviane@sorocaba.unesp.br; legfreitas_br@yahoo.com.br \\ ${ }^{2}$ USP, IB, Departamento de Ecologia, SP \\ E-mail: mpompeo@ib.usp.br
}

\begin{abstract}
The large population contingent and the precarious urban planning in the metropolitan region of São Paulo have resulted in uncontrolled growth in areas where springs exist, generating strong pressures on the reservoirs. Concomitantly, a lack of articulation between public and private policy has led to various socio-environmental conflicts in the Billings watershed. This spring, which is responsible for the direct and indirect supply of water to millions of people, represents an enormous challenge for water resource management. In this context, this study aimed to analyze the seasonal limnological conditions of the Billings Complex, in particular the Rio Grande and Taquacetuba branches, and discuss the implications for the management procedure applied in the branches. Physical (water temperature, $\mathrm{pH}$, electrical conductivity, suspended material, organic and inorganic suspended material) chemical (dissolved oxygen, total phosphorus and nitrogen, nitrate, nitrite, ammonium and inorganic phosphorus) and biological (chlorophyll-a) variables of the water were analyzed and the Trophic State Index was calculated. The results indicate a hypertrophic state in the Taquacetuba branch. The Rio Grande branch presented a mesotrophic state which is, however, artificially maintained due to copper sulfate and hydrogen peroxide treatments. The results are also discussed in light of CONAMA Resolution 357/2005. Levels of chlorophyll-a and total phosphorous in the Taquacetuba branch do not conform to the proposed class of use, class I. In this branch, monitoring must be intensified and measures adopted to reduce the level of nutrients in the main body of the Billings complex.
\end{abstract}

Keywords: reservoir; Billings; eutrophication; Rio Grande; Taquacetuba.

\section{Avaliação limnológica da água nos braços do Rio Grande e Taquacetuba no Compelxo Billings (São Paulo, Brasil) e as implicações para o manejo}

\section{RESUMO}

O grande contingente populacional e o precário planejamento urbano da região metropolitana de São Paulo resultaram em um crescimento desordenado nas regiões de mananciais, gerando forte pressão sobre os reservatórios. Concomitantemente, políticas desarticuladas entre órgãos públicos e privados levaram a diversas situações de conflito socioambiental na bacia da Billings. Esse manancial, responsável pelo abastecimento direto e indireto de milhões de pessoas, representa um importante desafio à gestão dos recursos hídricos no Brasil. Nesse contexto, o presente trabalho visou analisar sazonalmente as condições limnológicas do Complexo Billings nos braços do Rio Grande e Taquacetuba e as implicações ao manejo. Foram realizadas análises das variáveis físicas (temperatura da água, 
pH, condutividade elétrica e material em suspensão total - fração orgânica e inorgânica), químicas (oxigênio dissolvido, fósforo e nitrogênio totais, nitrato, nitrito, amônio e fosfato) e biológicas (clorofila-a) da água e calculado o Índice de Estado Trófico (IET), pela concentrações de fósforo total e clorofila-a. Os resultados indicam um estado de hipereutrofia no Taquacetuba, com risco à saúde pública, devido às florações de cianobactérias. O braço do Rio Grande apresentou um estado de mesotrofia, devido ao manejo realizado pela SABESP pela aplicação de algicida (sulfato de cobre) e de oxidante (peróxido de hidrogênio). Os resultados também foram discutidos à luz da Resolução CONAMA 357/2005. Os níveis de clorofila-a e fósforo total no braço do Taquacetuba não se encontra conforme a classe de uso proposta (classe I). Dessa forma, sugere-se que nesse braço, seja intensificado o monitoramento e sejam adotadas medidas para reduzir os níveis de nutrientes no corpo central do Complexo Billings.

Palavras-chave: reservatório, Billings, eutrofização, Rio Grande; Taquacetuba.

\section{INTRODUCTION}

The intense growth in urban centers and unplanned expansion of industrial and agricultural areas has been responsible for the process of eutrophication in reservoirs that provide the public water supply, mainly due to the punctual and diffuse dumping of domestic and industrial waste. Excessive levels of eutrophication provoke ecological imbalances with negative effects on the biota and degradation of water quality in the reservoir for multiple uses.

Among the innumerable negative effects of the eutrophication process, some that stand out include the degradation of water quality with alterations in composition, color, turbidity, and transparency, and an increase in organic decomposition with a consequent increase in consumption of dissolved oxygen to the point of anoxia. The resulting excess of nutrients in the mass can lead to intense and uncontrolled growth of aquatic macrophytes and phytoplankton, and finally, the production of toxic substances such as cyanotoxins, as well as potentially large losses in water use for public water supply, irrigation, hydroelectric use, recreation, tourism, and landscaping (Azevedo Neto, 1988).

The reservoirs are considered to be detectors of the impact of anthropic activities, as they are part of and reflect the consequences of land use and occupation surrounding the watershed (Tundisi, 1996). According to a study of 600 lakes and reservoirs around the world, the most common impacts are: degradation of water quality, decrease in water resources, loss of biodiversity, alterations in surface transportation, and perturbation and deterioration of fishing (Tundisi, 2005).

In Brazil, many urban eutrophic reservoirs for public supply are managed with the copper sulfate and the hydrogen peroxide applications, in order to control the growth of algae potentially toxic, the cyanobacteria. The copper sulfate is one of the pesticides more widely used in Brazil, in the agriculture such the "calda bordalesa", a preparation to the base of copper sulfate and lime (Carraro, 1997) or for the control of aquatic organisms, particularly phytoplankton (Cetesb, 2009). But there is reference of use in the control of the golden mussel, the Limnoperna fortunei, in the water treatment plant in Porto Alegre city (Rio Grande do Sul State, Brazil) (Colares et al., 2002) and in the aquatic macrophytes control (Mal et al., 2002).

The object of this study was to analyze the limnological conditions in two seasons (summer and winter) at two water catchment points in the Billings Complex used by the Basic Sanitation Company of the State of São Paulo (SABESP), specifically the Rio Grande and Taquacetuba branches. It also aimed to discuss the results based on Brazilian legislation, enabling evaluation of the consequences of current management practices for the environment. 
MOSCHINI-CARLOS, V. M.; FREITAS, L. G., POMPÊO, M. Limnological evaluation of water in the Rio Grande and Taquacetuba branches of the Billings Complex (São Paulo, Brazil) and management implications.

\section{MATERIALS AND METHODS}

\subsection{STUDY AREA}

This study was developed in the Taquacetuba and Rio Grande branches of the Billings Complex (Figure 1), at metropolitan region of São Paulo.

The Billings Reservoir is located west of the city of São Paulo, at $23^{\circ} 47^{\prime} \mathrm{S}$ and $46^{\circ} 40^{\prime}$ W, at an altitude of $746 \mathrm{~m}$, and covers areas of the municipalities of São Paulo, Santo André, São Bernardo do Campo, Diadema, Ribeirão Pires, and Rio Grande da Serra. Its watershed extends over $560 \mathrm{~km}^{2}$, bounded on the north by the watersheds of the Tamanduateí, Guaió, and Taiaçupeba rivers, all tributaries of the Tietê River (Cetesb, 1996). It has an area of approximately $120 \mathrm{~km}^{2}$ and a volume estimated at $1.20 \times 10^{9} \mathrm{~m}^{3}$, and it acts to regulate water flowing in from its own watershed as well water from the Tietê River, which reaches it via the Pinheiros River (Cetesb, op. cit.). The water in the reservoir is used for such ends as electrical energy generation, sanitation, leisure, and public water supply (EMAE, 2002). Morphologically, the Billings Reservoir has a narrow, elongated central body with several branches, some of large volume. The Billings reservoir is heterogeneous with biological and contamination characteristics that are spatially differentiated.

The Rio Grande branch extends for $9 \mathrm{~km}$, has an area of approximately $7.4 \mathrm{~km}^{2}$, and is located in the municipalities of São Bernardo do Campo, Santo André, Ribeirão Pires, and Rio Grande da Serra (Mariani, 2006). During the construction of the Via Anchieta viaduct in the 1940s, the Rio Grande branch was partially isolated from the Billings reservoir. The Rio Grande water treatment station (WTS), located near the dam, produces 4.2 thousand liters of water per second, supplying water to 1.2 million people in Diadema, São Bernardo do Campo, and part of Santo André. The Rio Grande branch also serves the cities of Ribeirão Pires and Rio Grande da Serra. Due to serious problems with cyanobacterial contamination, it was necessary to intercept the Rio Grande branch and change management practices to maintain proper water quality. Therefore, in 1981, the Rio Grande branch was definitively isolated from the Billings reservoir by the Anchieta dam, located below the Via Anchieta (Mariani, op. cit.). The Rio Grande reservoir is used for multiple purposes, serving as a locale for recreation, such as nautical sports, primary contact, fishing, and public supply. It also serves as a dumping place for industrial and domestic wastes from the cities of Ribeirão Pires and Rio Grande da Serra, as well as clandestine systems.

With the objective of regularizing the water supply for the Metropolitan Region of São Paulo, SABESP initiated the Metropolitan Water Program (PMA) in 1996, which included a series of construction projects aiming to achieve its goal by the year 2000 (Kussama et al., 1997). One of SABESP's priority goals included implantation of the TaquacetubaGuarapiranga Production System, which aimed to transpose the waters of the Taquacetuba branch of the Billings reservoir to the Guarapiranga reservoir to increase the supply of water to the population, and increase the use of the Billings reservoir for water supply. Water catchment was installed on the left bank of the Taquacetuba branch, flowing out of the south side of the Billings reservoir. The water catchment system consists of a floating structure that makes it possible to pump water at depths which prevent the re-suspension of sediments in the Billings reservoir as well as the flow of algae (Matsuzaki, 2007). In August of 2000, the Secretary of the Environment of the State of São Paulo granted an Environmental License for Operation for the first phase of the Taquacetuba-Guarapiranga Production System, corresponding to the transfer of a maximum flow of $2.0 \mathrm{~m}^{3} / \mathrm{s}$ of crude water. Due to the severe drought that occurred in 2000, the Secretary of the Environment of the State of São Paulo had the authority to grant a special license to transfer a flow of up to $4 \mathrm{~m}^{3} / \mathrm{s}$. In November of that same year, SABESP requested an emergency $2.0 \mathrm{~m}^{3} / \mathrm{s}$ increase, totaling $4.0 \mathrm{~m}^{3} / \mathrm{s}$ of water pumped out of the Billings reservoir into the Guarapiranga (Porto, 2003). 


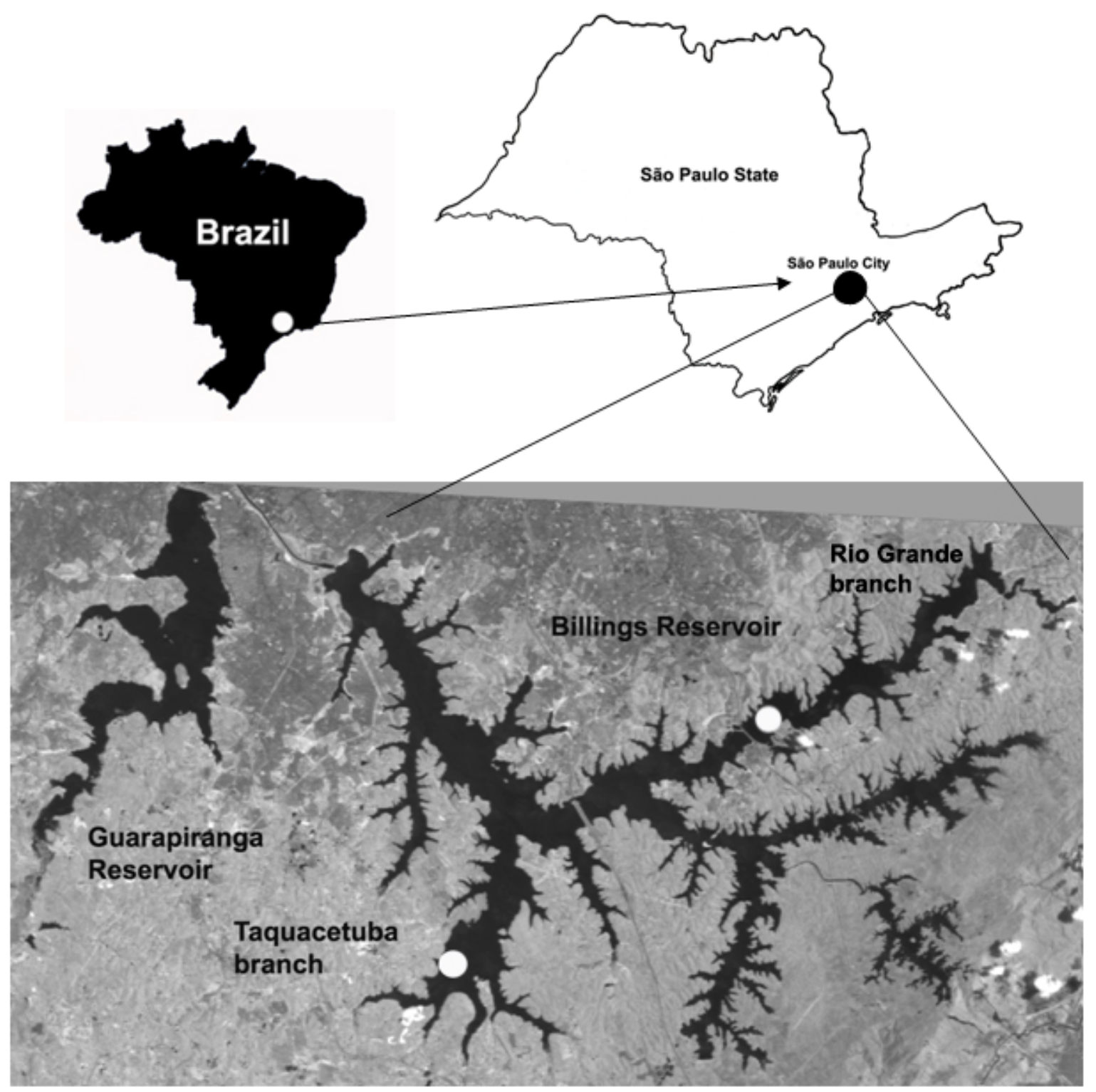

Figure 1. Billings Reservoir watershed (Rio Grande and Taquacetuba branch), near of São Paulo city, Brazil.

\subsection{WATER QUALITY PARAMETERS}

Water samples were collected from the sub-surface water column at points near the water catchment station of SABESP in the Rio Grande branch (342680 W and $7370305 \mathrm{~S}$ ) and the Taquacetuba branch (332285 W and $7342572 \mathrm{~S})$, in two seasons of the year, summer (February) and winter (July).

The $\mathrm{pH}$, water temperature and electrical conductivity were measured in situ with YSI (model 63/100 FT). Dissolved oxygen was measured for titulometric according Winkler method (Golterman et al., 1978) and suspended matter (organic and inorganic matter) by gravimetric method (Wetzel and Likens, 1991). Total phosphorus and total nitrogen were measured (Valderrama, 1981) and dissolved nutrients (nitrate and nitrite - Mackereth et al., 1978, ammonium - Koroleff, 1976), phosphate - Strickland and Parsons, 1960). 
MOSCHINI-CARLOS, V. M.; FREITAS, L. G., POMPÊO, M. Limnological evaluation of water in the Rio Grande and Taquacetuba branches of the Billings Complex (São Paulo, Brazil) and management implications. Ambi-Agua, Taubaté, v. 5, n. 3, p. 47-59, 2010. (doi:10.4136/ambi-agua.153)

The Trophic State Index (TSI) was calculated according to Lamparelli (2004):

TSI $(\mathrm{Chl})=10 \mathrm{x}(6-((0,92-0,34 \mathrm{x}(\operatorname{lnCL}) / \ln 2))$

TSI $(\mathrm{TP})=10 \times(6-((1,77-0,42 \times(\ln T P) / \ln 2))$

where: $\mathrm{Chl}=$ Chlorophyll-a $\left(\mu \mathrm{g} . \mathrm{L}^{-1}\right)$; and $\mathrm{TP}=$ Total phosphorous $\left(\mu \mathrm{g} . \mathrm{L}^{-1}\right)$

The limits defined were: Ultra-Oligotrophic: $\leq 47$, Oligotrophic: $47<$ TSI $\leq 52$, Mesotrophic: $52<$ TSI $\leq$ 59, Eutrophic: $59<$ TSI $\leq 63$, Supereutrophic: $63<$ TSI $\leq 67$ and Hypereutrophic: $>67$.

The results are also discussed in light of CONAMA Resolution $n^{\circ} 357$ (Brasil, 2005) provides a classification of bodies of water and a framework of environmental directives, and establishes conditions and standards for dumping waste, among other measures.

\section{RESULTS AND DISCUSSION}

\subsection{Physical, chemical, and biological variables of the water}

Results of analyses of the physical, chemical, and biological variables of the surface water for the two stations (Taquacetuba and Rio Grande), for February and July, are presented in Table 1.

Table 1. Physical, chemical, and biological variables for water surface in February and July of 2007 in the Rio Grande and Taquacetuba branches (Billings Reservoir, SP, Brazil).

\begin{tabular}{l|rr|rr}
\hline \multicolumn{1}{c|}{ Variables } & \multicolumn{2}{c|}{ Rio Grande } & \multicolumn{2}{c}{ Taquacetuba } \\
\hline & February & July & February & July \\
\hline Water temperature $\left({ }^{\circ} \mathrm{C}\right)$ & 27.0 & 19.2 & 25.2 & 19.5 \\
Electrical conductivity $\left(\mu \mathrm{S} . \mathrm{cm}^{-1}\right)$ & 182.2 & 190.5 & 145.1 & 7.1 \\
$\mathrm{pH}$ & 7.7 & 7.7 & 7.8 & 7.6 \\
Dissolved oxygen $\left(\mathrm{mg} . \mathrm{L}^{-1}\right)$ & 7.1 & 8.4 & 8.8 & 6.2 \\
Suspended material $\left(\mathrm{mg} . \mathrm{L}^{-1}\right)$ & 2.6 & 2.7 & 88.7 & 164.0 \\
Organic suspended material $(\%)$ & 90.5 & 73.8 & 11.2 & 95.1 \\
Inorganic suspended material $(\%)$ & 9.5 & 26.2 & 473.6 & 4.9 \\
Total nitrogen $\left(\mu \mathrm{g} . \mathrm{L}^{-1}\right)$ & 162.1 & 421.1 & 336.8 & 281.6 \\
Nitrate $\left(\mu \mathrm{g} . \mathrm{L}^{-1}\right)$ & 77.0 & 461.0 & 25.7 & 8.1 \\
Nitrite $\left(\mu \mathrm{g} . \mathrm{L}^{-1}\right)$ & 10.0 & $<5.0$ & 20.1 & $<4.2$ \\
Ammonium $\left(\mu \mathrm{g} . \mathrm{L}^{-1}\right)$ & 176.0 & $<4.2$ & 54.6 & 402.2 \\
Total phosphorous $\left(\mu \mathrm{g} . \mathrm{L}^{-1}\right)$ & 40.1 & 36.6 & $<10.0$ & 11.7 \\
Inorganic phosphorous $\left(\mu \mathrm{g} . \mathrm{L}^{-1}\right)$ & 10.8 & 36.6 & 33.2 & 867.0 \\
Chlorophyll $a\left(\mu \mathrm{g} . \mathrm{L}^{-1}\right)$ & 5.6 & 4.7 & &
\end{tabular}

The highest water temperatures were detected in February $-27.0^{\circ} \mathrm{C}$ (hot, rainy season) compared to July $-19.2^{\circ} \mathrm{C}$ (cold, dry season) (Table 1), which characterizes well the influence of seasonality on water temperatures.

The $\mathrm{pH}$ of the water was found do be slightly basic in both seasons and environments. Dissolved oxygen concentrations were $7.1 \mathrm{mg} . \mathrm{L}^{-1}$ (February) and $8.4 \mathrm{mg} . \mathrm{L}^{-1}$ (July) in the Rio Grande branch and $7.4 \mathrm{mg} . \mathrm{L}^{-1}$ (February) and $6.2 \mathrm{mg} . \mathrm{L}^{-1}$ (July) in the Taquacetuba branch.

Electrical conductivity values of the water were high in both environments, with the highest observed in July in the Taquacetuba branch (ranged from 182.8 to $204.1 \mu \mathrm{S} . \mathrm{cm}^{-1}$ ). Calijuri et al. (1999) recorded values of $159 \mu \mathrm{S}_{\mathrm{cm}} \mathrm{cm}^{-1}$ approximately for the Salto Grande Reservoir (Americana, SP) and classified it as hypertrophic.

With respect to total suspended material (TSM), the Taquacetuba branch also presented higher levels in July $\left(164.0 \mathrm{mg} . \mathrm{L}^{-1}\right)$. In both environments and periods of the year, levels of organic suspended material (ranged from 73.8 to 95.1\%) were much higher than levels of inorganic material (ranged from 4.9 to $26.2 \%$ ), which is reflected in the elevated algae biomass (Table 1). 
Total nitrogen concentrations were elevated in both periods in the Taquacetuba branch (ranged from 431.6 to $\left.473.6 \mu \mathrm{g} / \mathrm{L}^{-1}\right)$ and in July in the Rio Grande branch $\left(421.1 \mu \mathrm{g} / \mathrm{L}^{-1}\right)$, reflecting high concentrations of nitrate. Low concentrations of ammonium ion were found in both periods in the Taquacetuba branch, ranged from $<4.2$ to $20.1 \mu \mathrm{g} / \mathrm{L}^{-1}$. Since ammonium ion is the preferred source of nitrogen, it is probably incorporated into the phytoplankton mass. Nitrite levels were found to be low in both periods and locales, ranged from $<5.0$ to $25.7 \mu \mathrm{g} / \mathrm{L}^{-1}$ (Table 1$)$.

Total phosphorous concentrations were higher in the Taquacetuba branch in July (402.2 $\mu \mathrm{g} / \mathrm{L}^{-1}$ ), the period of greater algae mass (Cyanobacteria). Inorganic phosphate was relatively low in both periods and both locales, ranged from $<10.0$ to $36.6 \mu \mathrm{g} / \mathrm{L}^{-1}$. Chlorophyll-a values were higher in the Taquacetuba branch (ranged from 33.2 to $867.0 \mu \mathrm{g} / \mathrm{L}^{-1}$ ) than in the Rio Grande branch (ranged from 4.7 to $5.6 \mu \mathrm{g} / \mathrm{L}^{-1}$ ), indicating a greater degree of eutrophication (Table 1). The higher chlorophyll-a value detected in July in the Taquacetuba branch was probably due to a cyanobacteria bloom event. Calijuri et al. (1999) found chlorophyll-a values ranging from 10.9 to $73.2 \mu \mathrm{g} . \mathrm{L}^{-1}$ in the hyper-eutrophic Salto Grande Reservoir (Americana city, SP).

\subsection{Trophic state index}

The Taquacetuba branch was classified as super-eutrophic in February and hypereutrophic in July, and the Rio Grande branch was classified as mesotrophic in both periods (Table 2). These results confirm the difference in trophic state between the two systems studied. The Taquacetuba branch is more eutrophized than the Rio Grande branch, reflecting different management procedures applied in each branch.

When the trophic state index (TSI) is compared to other points in the Billings Complex monitored by CETESB (Cetesb, 2007), one observes that the greater the distance from, or the lesser the connectivity with, the compartment near the Pedreira dam (the receiving point for water from the Pinheiros River), the lesser the degree of eutrophication. The crude water in the Taquacetuba branch receives no treatment, with management being applied only to the water downstream in the Guarapiranga reservoir.

Table 2. Trophic State Index (TSI) according to Carlson (1977 and Toledo et al. 1983, modified by Lamparelli, 2004) for the Rio Grande and Taquacetuba branches in February and July of 2007.

\begin{tabular}{c|lccl}
\hline Month & Locale & Values & Classification & \multicolumn{1}{c}{ Limits } \\
\hline February & Taquacetuba & 65 & Supereutrophic & Ultraoligotrophic: TSI $\leq 47$ \\
& Rio Grande & 56 & Mesotrophic & Oligotrophic : $47<$ TSI $\leq 52$ \\
\hline \multirow{2}{*}{ July } & Taquacetuba & 75 & Hypereutrophic & Mesotrophic: $52<$ TSI $<59$ \\
& Rio Grande & 55 & Mesotrophic & Eutrophic: $59<$ TSI $\leq 63$ \\
& & & & Supereutrophic: $63<$ TSI $\leq 67$ \\
& & & & Hypereutrophic: TSI $>67$ \\
\hline
\end{tabular}

\subsection{CONAMA Resolution $n^{0} 357$ of 17/03/2005}

This resolution CONAMA Resolution $\mathrm{n}^{0} 357$ of 17/3/2005 (Brasil, 2005), provides the limits of standards to be measured in five classes of bodies of water defined by their predominant uses. The special classes I and II are for more prime uses, such as human water supply, watering livestock, and protection of aquatic life, with different degrees of treatment of crude water. Class II may also be intended for human water supply, but following treatment using conventional or advanced processes. Class IV is used for landscaping and navigation. The standards established for the classes of use that are relevant to this study are presented in Table 3 . 
For bodies of water in the State of São Paulo, standards are defined by State Decree 10.755 (São Paulo, 1977). According to this decree, the Rio Grande branch is class II while the Taquacetuba branch is class I.

Based on the standards established by CONAMA Resolution $n^{\circ} 357 / 05$ (Brasil, 2005), levels of nitrate, nitrite, and ammonium found in this study conform to class II for the Rio Grande branch. For total phosphorous, both the Rio Grande and the Taquacetuba branches conform to class II in the month of February, but to class IV in July. For chlorophyll-a level, the Rio Grande branch conforms to class I in both periods, and the Taquacetuba branch to class III in February and class IV in July. Thus, for chlorophyll-a and total phosphorous measured on the surface of the Taquacetuba branch in both periods of the year, levels exceed the limits established for class II; in other words, the water does not conform to the use class defined by the framework of standards. This finding is of great concern, since not only does the Taquacetuba branch not conform to the standards, but in addition, its lowest quality water flows into the Guarapiranga reservoir which, based on Decree 10.755, is categorized as class I, which can compromise the uses proposed for this class, mainly public water supply to the metropolitan region of São Paulo.

Table 3. Freshwater quality standards based on usage, according to CONAMA Resolution $\mathrm{n}^{\mathrm{o}} 357$ (Brasil, 2005).

\begin{tabular}{l|ccccc}
\hline \multicolumn{1}{c}{ Parameters } & Unit & Class I & Class II & Class III & Class IV \\
\hline $\begin{array}{l}\text { Dissolved } \\
\text { oxygen }\end{array}$ & mg. $\mathrm{L}^{-1}$ & $>6$ & $>5$ & $>4$ & $>2,0$ \\
$\mathrm{pH}$ & & 6.0 to 9.0 & 6.0 to 9.0 & 6.0 to 9.0 & 6.0 to 9.0 \\
$\begin{array}{l}\text { Total } \\
\text { phosphorous }\end{array}$ & $\mathrm{mg} \cdot \mathrm{L}^{-1}$ & $<0.02$ & $<0.030$ & $<0.05$ \\
Nitrate & $\mathrm{mg} \cdot \mathrm{L}^{-1}$ & $<10$ & $<10$ & $<10$ \\
Nitrite & $\mathrm{mg} \cdot \mathrm{L}^{-1}$ & $<1$ & $<1$ & $<1$ \\
Ammonium & $\mathrm{mg} \cdot \mathrm{L}^{-1}$ & $<3.7$ for $\mathrm{pH}<7.5$ & $<3.7$ for $\mathrm{pH}<7.5$ & $<13.3$ for $\mathrm{pH}<7.5$ \\
& & $<2.0$ for $7.5<\mathrm{pH}<8.0$ & $<2.0$ for $7.5<\mathrm{pH}<8.0$ & $<5.6$ for $7.5<\mathrm{pH}<8.0$ \\
& & $<1.0$ for $8.0<\mathrm{pH}<8.5$ & $<1.0$ for $8.0<\mathrm{pH}>8.5$ & $<2.2$ for $8.0<\mathrm{pH}<8.5$ \\
& $<0.5$ for $\mathrm{pH}>8.5$ & $<0.5$ for $\mathrm{pH}>8.5$ & $<1.0$ for $\mathrm{pH}>8.5$ \\
Chlorphyll a & $\mu \mathrm{g} . \mathrm{L}^{-1}$ & $<10$ & $<30$ & $<60$ & \\
\hline
\end{tabular}

\subsection{Implications for management in the Rio Grande and Taquacetuba branches}

SABESP carries out a management procedure with the crude water of the Rio Grande branch that involves application of the oxidant hydrogen peroxide and the algaecide copper sulfate. The copper sulfate causes lysis of the cyanobacteria cells, liberating toxins into the water (Zagatto et al., 1997), while the hydrogen peroxide oxidizes the organic matter and does not eliminate all the toxins, which can remain in the water supply.

The use of large quantities of the algaecide copper sulfate to manage cyanobacteria can compromise the public water supply and health of the population. It should be noted that the application of algaecides is prohibited by Decree 518/2004 of the Ministry of Health when the density of cyanobacteria exceeds 20,000 cells. $\mathrm{mL}^{-1}$ (or $2 \mathrm{~mm}^{3} \cdot \mathrm{L}^{-1}$ of biovolume), as it can interfere with the evaluation of health risks associated with cyanotoxins (Art. 19, §2, Brasil, 2004). Many incidents of harm to human health have been associated with the cellular lysis of cyanobacteria, which following treatment with copper sulfate, leads to the liberation of large quantities of toxins into the water (Matsuzaki, 2007). According to Beyruth (2000), the application of copper sulfate to the water constitutes an unsatisfactory, palliative emergency measure. Nevertheless, the application of algaecides such as copper sulfate and hydrogen peroxide has been the main management procedure for decades. The appropriate procedure would be to apply algaecide only in rare and extreme situations. 
MOSCHINI-CARLOS, V. M.; FREITAS, L. G., POMPÊO, M. Limnological evaluation of water in the Rio Grande and Taquacetuba branches of the Billings Complex (São Paulo, Brazil) and management implications. Ambi-Agua, Taubaté, v. 5, n. 3, p. 47-59, 2010. (doi:10.4136/ambi-agua.153)

In 2008 was applied 350 tons of copper sulfate in the Guarapiranga Reservoir, but only December 2008 reached 70 ton (Table 4) (Cetesb, 2009). In the Rio Grande arm (Billings Reservoir), in 2004 (January, March, April and November) the copper sulfate values applied reached 50 ton, while in 2005 got down 20 ton (Cetesb, 2006). According Cetesb (op. cit.), for the Guarapiranga Reservoir the copper sulfate application ranged between 8 tons monthly (September) and 49 tons (November) in 2005, values that were similar to that applied in 2004. For the years 2006 and 2007 significant applications of copper sulfate occurred in Billings (arm Rio Grande), Guarapiranga and Paiva Castro Reservoirs (Table 4). More recently in the Paiva Castro Reservoir, located in the metropolitan region of São Paulo city, near the municipality of Mairiporã, applications occur mainly in summer. There are also regular applications of copper sulfate for phytoplankton control in Lake Paranoá (Distrito Federal, Brazil) (Padovesi-Fonseca and Philomeno, 2004) and Jundiai Reservoir (São Paulo) (Table 4).

Table 4. Annual application of copper sulfate in the Jundiaí, Guarapiranga and Billings Reservoirs (arm Rio Grande) (years 2006, 2007 and 2008) and monthly values (in brackets) with a peak in the application year. According Cetesb (2007, 2008 and 2009).

\begin{tabular}{|c|c|c|c|c|}
\hline \multirow[t]{2}{*}{ Reservoir } & \multicolumn{4}{|c|}{$\begin{array}{c}\text { Year }^{(*)} \\
\text { Ton }\end{array}$} \\
\hline & 2005 & 2006 & 2007 & 2008 \\
\hline $\begin{array}{l}\text { Jundiaí } \\
\text { Guarapiranga } \\
\text { Rio Grande }\end{array}$ & & $\begin{array}{l}<20 \\
350 \\
150\end{array}$ & $\begin{array}{c}42 \\
440 \\
360\end{array}$ & 350 \\
\hline $\begin{array}{l}\text { Jundiaí } \\
\text { Guarapiranga } \\
\text { Rio Grande }\end{array}$ & 49 (November) & $\begin{array}{c}5 \text { (October) } \\
>60 \text { (January) } \\
44 \text { (March) }\end{array}$ & $\begin{array}{c}16 \text { (December) } \\
76 \text { (September) } \\
62 \text { (August) }\end{array}$ & 70 (December) \\
\hline
\end{tabular}

$(*)$ Estimated values.

The various soluble forms of copper present in fresh and salt water are $\mathrm{Cu}^{2+}, \mathrm{Cu}\left(\mathrm{HCO}_{3}\right)$ and $\mathrm{Cu}(\mathrm{OH})_{2}$. In $\mathrm{pH}$ and carbonates concentrations characteristics of natural waters, most part of $\mathrm{Cu}$ (II) dissolved is observed mainly in complex form and not free (metallic form) (WHO, 1998 apud Pedrozo, 2003; Barceloux, 1999). Thus, only a small part of copper is present as free form $\left(\mathrm{Cu}^{+2}\right)$, and most part are adsorbed to particulate matter or complexed, mainly carbonates and hydroxides. However, the most part of copper is bound to organic compounds such as humic and fulvic acids (Pedrozo, op cit.).

For fish, more so than for humans, high doses of copper are extremely harmful (Cetesb, 2003). According to this author, trout, carp, catfish and goldfish, die in dosages of $0.5 \mathrm{mg} . \mathrm{L}^{-1}$. Fish die by the coagulation of mucus in the gills and consequent asphyxia (Cetesb, op cit.).

The microorganisms perish in concentrations higher than $1.0 \mathrm{mg} . \mathrm{L}^{-1}$. Copper used in form of copper sulfate pentahydrate $\left(\mathrm{CuSO}_{4} .5 \mathrm{H}_{2} \mathrm{O}\right)$ in doses of $0.5 \mathrm{mg}$. $\mathrm{L}^{-1}$ is considered a powerful algaecide and much used in Brazil (Cetesb, 2007, 2008, 2009). The Water Quality Criteria indicates the concentration of $1.0 \mathrm{mg} . \mathrm{L}^{-1}$ copper as the maximum allowable water reserved for public supply.

For adults the dose of copper sulfate emetic is 0.25 to $0.5 \mathrm{~g}$, expressed as $\mathrm{Cu}$. The ingestion of food or drinks containing $25 \mathrm{mgCu} . \mathrm{L}^{-1}$ is associated with acute gastroenteritis. For doses above $250 \mathrm{mgCu} / \mathrm{kg} /$ day, in animals produce liver necrosis (Barceloux, 1999).

As an essential element for all biota, there is reference to bioaccumulation of copper in some groups of organisms, however, seems not to occur copper biomagnifications in the food chain, no increase of its concentration in higher trophic levels (Pedrozo, 2003).

The most appropriate action would be for the State to take preventive measures to control land use and occupation, aiming to maintain better water quality, including zero dumping, 
MOSCHINI-CARLOS, V. M.; FREITAS, L. G., POMPÊO, M. Limnological evaluation of water in the Rio Grande and Taquacetuba branches of the Billings Complex (São Paulo, Brazil) and management implications. Ambi-Agua, Taubaté, v. 5, n. 3, p. 47-59, 2010. (doi:10.4136/ambi-agua.153)

with $100 \%$ collection and treatment of waste water generated in the watersheds of the Rio Grande and the Taquacetuba. To decrease the negative impacts of the eutrophication process in the Taquacetuba branch, it would also be helpful to improve the quality of the water from the Pinheiros River, which would imply actions in its watershed, as well.

Mariani and Pompêo (2008) detected high concentrations of copper in sediment in the Rio Grande branch of the Billings Complex, from the high to the low part, near the water catchment point of the Rio Grande Water Treatment Station, where 1,192.17 mg.kg-1 were recorded. The authors claim that this high level of copper near the Rio Grande Water Treatment Station can be attributed to the application of copper sulfate algaecide in the reservoir to control cyanobacteria. The data also show that concentrations of the trace metal copper in the sediment at specific points of the Rio Grande branch were found to be as much as 102.7 times above regional reference values, as established by Nascimento (unpublished data), and copper concentrations in the sediment in various points upstream from the collection point for the present study were significantly elevated, nearly 18 times above the Probable Effect Level defined by the Canadian Council of Ministers of the Environment (CCME, 2003).

Mariani (2010) showed that the sediment of the Rio Grande arm, located near the Parque Municipal Estoril and water crud supply station (São Bernardo do Campo city) have values above the reference concentration for toxicity (CCME, 2003) to about 30, 9, 5 and 8 times for copper, cadmium, chromium and nickel, respectively.

According to Cetesb (2007), the concentration of dissolved copper at the water catchment point near the Rio Grande arm, almost in all months, was above the limit established by CONAMA Resolution 357/05 for class II. These elevated levels of copper found in the sediment and the water column of the Rio Grande branch point to the need for Measure to control the application of copper sulfate.

According to the Report on Water Quality in the Interior of the State of São Paulo (Cetesb, 2007), the Rio Grande presented high densities of cyanobacteria. In July, values reached 71,600 cells.mL ${ }^{-1}$, exceeding the limits established by Law for drinking water $\left(20,000\right.$ cells. $\left.\mathrm{mL}^{-1}\right)$. In the winter, with the decrease in water quality, the use of copper sulfate and hydrogen peroxide is increased, reaching $100,000 \mathrm{~kg}$ of chemical algaecides in July. In the summer, the opposite occurs, with little more than $20,000 \mathrm{~kg}$ of algaecides. A total of more than 500 tons of algaecides were used in the Rio Grande branch in 2007.

The data collected for this study show that the Taquacetuba branch is in an accelerated process of eutrophication. The most evident consequence of this degradation has been cyanobacteria blooms which are potentially toxic. According to Cetesb (2007), elevated percentages cyanobacteria were detected in water samples taken from the Taquacetuba, with chronic toxic effects, demonstrating that the water quality is extremely compromised in ecotoxicological terms, due to cyanobacteria blooms. Matsuzaki (2007) and Moschini-Carlos et al. (2009) also emphasized the frequency with which cyanobacteria blooms have been occurring in these environments.

Moschini-Carlos et al. (2009) found low richness and high dominance of cyanobacteria in February and July of 2007 in the Rio Grande and Taquacetuba branches. Cylindrospermopsis raciborskii predominated in February, with 12,894 ind. $\mathrm{mL}^{-1}$, and Anabaena spiroides was predominant in July, with 37,524 ind. $\mathrm{mL}^{-1}$. Regarding the cyanotoxins, three variants of microcystin (MC-RR, MC-LR, MC-YR) were found in the sample taken in February, as well as saxitoxin. The sample taken in July presented the same variants of microcystin, but in lower concentrations, and no saxitoxin was detected. These results are of great concern, as the crude water in the Taquacetuba branch, which is diverted into the Guarapiranga reservoir, receives no treatment or management.

The transposition of the water from the Taquacetuba into the Guarapiranga System follows technical standards for environmental licensing which include the adoption of a 
contingency plan when cyanobacteria blooms occur. The first version of the contingency plan for the occurrence of cyanobacteria in the Billings-Guarapiranga System was presented by SABESP in May of 2002. Following analysis of monitoring data collected from 2000 to 2005, alterations to the plan were proposed. Regarding monitoring, the plan includes weekly samplings in the Guarapiranga and every 15 days in the Taquacetuba. When the presence of cyanobacteria exceeds established limits, SABESP will reduce to $2.0 \mathrm{~m}^{3} . \mathrm{s}^{-1}$ or suspend pumping, communicating to the Secretary of the Environment and Cetesb to plan emergency meetings with the State Secretary of Health (Matsuzaki, unpublished data).

Like the Rio Grande, the Guarapiranga reservoir also receives treatments with high levels of algaecides. According to Cetesb (2007), this reservoir received more than 450 tons of copper sulfate in 2007 , in addition to hydrogen peroxide.

\section{CONCLUSIONS}

The Taquacetuba branch is in a more advanced state of eutrophication than the Rio Grande. However, the eutrophication of the Rio Grande branch is artificial, reflecting the management carried out in this branch with application of copper sulfate and hydrogen peroxide.

Levels of chlorophyll-a and total phosphorous in the Taquacetuba branch do not conform to the proposed class of use, class I. In this branch, monitoring must be intensified and measures adopted to reduce the level of nutrients in the main body of the Billings complex, in the region of the Pedreira dam, which will be reflected in the eutrophication process and its secondary effects, such as the intense growth of potentially toxic algae.

\section{ACKNOWLEDGMENTS}

The authors would like to thank São Paulo Research Foundation (FAPESP Proc. No 2002/13376-4, 2006/51705-0, 2008/00784-3, 2009/16652-1), and the University of São Paulo (USP) and São Paulo State University (UNESP), for making the infrastructure available.

\section{REFERENCES}

AZEVEDO NETO, J. M. Novos conceitos sobre eutrofização. Revista DAE, v. 48, n. 151, p. 22-28, 1988.

BARCELOUX, D. G. Copper. Clinical Toxicology, v. 37, n. 2, p. 217-230, 1999.

BEYRUTH, Z. As algas e a previsão da qualidade ambiental na represa do Guarapiranga. In: CONGRESSO INTERAMERICANO DE INGENIERIA SANITARIA Y AMBIENTAL, 27., 03 a 08 de dezembro de 2000, Porto Alegre. Las Américas y la acción por ela medio ambiente en el milenio. Anais... Porto Alegre: AIDIS, 2000. p. 1-6.

BRASIL. Ministério do Meio Ambiente. Conselho Nacional do Meio Ambiente. Resolução CONAMA no. 357. Dispõe sobre a classificação das águas doces, salobras e salinas do território nacional. Diário Oficial [da] República Federativa do Brasil, Poder Executivo, Brasília, DF, 17 mar. 2005. 
BRASIL. Ministério da Saúde. Portaria $n^{\circ}$ 518, de 25 de março de 2004. Estabelece os procedimentos e responsabilidade relativos ao controle e vigilância da qualidade da água para consumo humano e seu padrão de potabilidade, e dá outras providências. Diário Oficial [da] República Federativa do Brasil, Poder Executivo, Brasília, DF, 25 mar. 2004.

CARRARO, G. Agrotóxico e meio ambiente: uma proposta de ensino de ciências e química. Porto Alegre: Universidade Federal do Rio Grande do Sul, Instituto de Química, Área de Educação, Química, 1997. p. 95. Disponível: <http://www.iq.ufrgs.br/aeq/html/publicacoes/ matdid/livros/pdf/agrotoxicos.pdf>. Acesso: maio 2010.

CANADIAN COUNCIL OF MINISTERS OF THE ENVIRONMENT - CCME. Summary of existing canadian environmental quality guidelines. Canadian sediment quality guidelines for the protection of aquatic life. 2003. Disponível em: <http://www.ccme.ca/ assets/pdf/sedqg_summary_table.pdf $>$. Acesso: maio 2010.

CALIJURI, M. C.; DEBERDT, G. L. B.; MINOTI, R. T. A produtividade primária pelo fitoplâncton na represa de Salto Grande (Americana - SP). In: HENRY, R. (Ed.). Ecologia de reservatórios: estrutura, função e aspectos sociais. Botucatu: FAPESP/FUNDIBIO, 1999. p. 409-448.

COLARES, E. R. C.; SUMINSKY, M.; BENDATI, M. M. A. Diagnóstico e controle do mexilhão-dourado, Limnoperna fortunei, em sistemas de tratamento de água em Porto Alegre (RS, Brasil). In: SIMPÓSIO ÍTALO BRASILEIRO DE ENGENHARIA SANITÁRIA E AMBIENTAL, 6., 2002, Vitória. Disponível em: $<$ http://www.bvsde.paho.org/bvsacd/sibesa6/vdos.pdf>. Acesso: maio de 2010.

COMPANHIA DE TECNOLOGIA E SANEAMENTO AMBIENTAL - CETESB. Avaliação do Complexo Billings: comunidades aquáticas - (Out/92 a Out/93), São Paulo: DAH, 1996.

COMPANHIA DE TECNOLOGIA E SANEAMENTO AMBIENTAL - CETESB. Relatório de qualidade das águas interiores no Estado de São Paulo 2002. São Paulo: Secretaria de Estado do Meio Ambiente, 2003. 279p.

COMPANHIA DE TECNOLOGIA E SANEAMENTO AMBIENTAL - CETESB. Relatório de qualidade das águas interiores no Estado de São Paulo 2002. São Paulo: Secretaria de Estado do Meio Ambiente, 2006. 488p.

COMPANHIA DE TECNOLOGIA E SANEAMENTO AMBIENTAL - CETESB. Relatório de qualidade das águas interiores no Estado de São Paulo 2006. São Paulo: Secretaria de Estado do Meio Ambiente, 2007. 327p.

COMPANHIA DE TECNOLOGIA E SANEAMENTO AMBIENTAL - CETESB. Relatório de qualidade das águas interiores no Estado de São Paulo 2006. São Paulo: Secretaria de Estado do Meio Ambiente, 2008. 537p.

COMPANHIA DE TECNOLOGIA E SANEAMENTO AMBIENTAL - CETESB. Relatório de qualidade das águas interiores no Estado de São Paulo 2006. São Paulo: Secretaria de Estado do Meio Ambiente, 2009. 528p.

EMPRESA METROPOLITANA DE ÁGUAS E ENERGIA S.A. - EMAE. 2002. Disponível em: <http://www.emae.sp.gov.br>. Acesso: 26 jul. 2002. 
GOLTERMAN, H. L.; CLYMO, R. S.; OHNSTAD, M. A. M. Methods for physical and chemical analysis of freshwaters. 20. ed. Oxford: Blackwell Scientific Publications, I.B.P. Handbook, 1978. 213 p.

KOROLEFF, F. Determination of nutrients. In: GRASSHOFF, K. (Ed.). Methods of seawater analysis. New York: Verlag Chemie Weinhein, 1976. p. 117-181.

KUSSAMA, A. C.; TOMMASI, L. R.; BATALHA, B. H. L.; FERRARI, I.; GARCIA, M.; TOMITA, N. Y.; ORLANDI, A. R. Interligação do Braço do Taquacetuba/Billings Reservatorio Guarapiranga: replicando em defesa da saúde pública. Revista do Instituto de Engenharia, v. 55, n. 523, p. 59-70, 1997.

LAMPARELli, M. C. Graus de trofia em corpos d’água do Estado de São Paulo: avaliação dos métodos de monitoramento. 2004. 234f. Tese (Doutorado em Ecologia) - Universidade de São Paulo, São Paulo, 2004.

MACKERETH, F. J. H.; HERON, J.; TALLING, J. F. Water analysis: some revised methods for limnologists. Freshwater Biological Association, n. 36, p. 121, 1978.

MAL, T. K.; ADORJAN, P.; CORBETT, A. L. Effect of copper on growth of an aquatic macrophyte, Elodea Canadensis. Environmental Pollution, v. 120, n. 2, p. 307-311, 2002.

MARIANI, C. F. Reservatório Rio Grande: caracterização limnológica da água e biodisponibilidade de metais-traço no sedimento. 2006. 138f. Dissertação (Mestrado em Ecologia) - Universidade de São Paulo, São Paulo, 2006.

MARIANI, C. F. Variação temporal do teor de SVA/ MES e avaliação integrada do sedimento do Braço do Rio Grande (Complexo Billings - SP). 2010. 166f. Tese (Doutorado em Ecologia) - Universidade de São Paulo, São Paulo, 2010.

MARIANI, C. F.; POMPÊO M. L. M. Potentially bioavailable metals in sediment from a tropical polymictic environment Rio Grande Reservoir, Brazil. Journal of Soils and Sediments, v. 8, p. 284-288. 2008.

MATSUZAKI, M. Transposição das águas do Braço Taquacetuba da Represa Billings para a Represa Guarapiranga: aspectos relacionados à qualidade de água para abastecimento. 2007. 183f. Tese (Doutorado em Saúde Pública) - Universidade de São Paulo, São Paulo, 2007.

MOSCHINI-CARLOS, V.; BORTOLLI, S.; PINTO, E.; NISHIMURA, P. Y.; FREITAS, L. G.; POMPÊ, M. L. M.; DORR, F. Cyanobacteria and cyanotoxin in the Billings Reservoir (São Paulo, SP, Brazil). Limnetica, v. 28, n. 2, p. 273-282, 2009.

PADOVESI-FONSECA, C.; PHILOMENO, M. G. Effects of algicide (copper sulfate) application on short-term fluctuations of phytoplankton in Lake Paranoá, Central Brazil. Braz. J. Biol., v. 64, n. 4, p. 819-826, 2004.

PEDROZO, M. F. M. Cobre. In: AZEVEDO, F. A.; CHASIN, A. A. M. Metais: gerenciamento da toxicidade. São Paulo: Atheneu, 2003. 554p.

PORTO M. Recursos hídricos e saneamento na Região Metropolitana de São Paulo: um desafio do tamanho da cidade. Brasília: Banco Mundial, 2003. 84p. 
SÃO PAULO (Estado). Decreto Estadual $\mathrm{n}^{\circ}$ 10.755, de 22 de novembro de 1977. Dispõe sobre o enquadramento dos corpos de água receptores na classificação prevista no Decreto $\mathrm{n}^{\circ}$ 8.468, de 8 de setembro de 1976 e da providências correlatas. Diário Oficial [do] Estado de São Paulo, São Paulo, 22 de nov. 1977.

STRICKLAND, J. D.; PARSONS, T. R. A manual of seawater analysis. Bull Fihs Res Bel Can, v. 125, p. 1-185, 1960.

TUNDISI, J. G. Reservoir as complex systems. Ciência e Cultura, v. 48, n. 5/6, p. 383-387, 1996.

TUNDISI, J. G. Gerenciamento integrado de bacias hidrográficas e reservatórios: estudos de caso e perspectivas. In: NOGUEIRA, M. G.; HENRY, R.; JORCIN, A. (Org.) Ecologia de reservatórios: impactos potenciais, ações de manejo e sistemas em cascata. São Carlos: Rima, 2005.

VALDERRAMA, G. C. The simultaneous analysis of total nitrogen and total phosphorus in natural waters. Marine Chemical, v. 10, p. 109-122, 1981.

WETZEL, R. G.; LIKENS, G. E. Limnological Analyses. New York: Springer-Verlag, 1991. $391 \mathrm{p}$.

ZAGATTO, P. A.; ARAGÃO, M. A.; CARVALHO, M. C.; SOUZA, R. C. R. Manual de orientação em casos de florações de algas tóxicas: um problema de saúde pública. São Paulo: CETESB, 1997. (Manuais, 14). 